\title{
STUDY ON HYDRATION AND STRENGTHENING OF HIGH ALUMINA CEMENTS
}

\author{
Nicolae ANGELESCU ${ }^{1}$, Cristina STANCU ${ }^{2}$, Sofiane AMZIANE ${ }^{3}$, \\ Vasile BRATU ${ }^{1}$, Elena Valentina STOIAN ${ }^{1}$ \\ ${ }^{1}$ Valahia University of Targoviste, Faculty of Materials Engineering and Mechanics, \\ Department of Materials Engineering, Mechatronics and Robotics \\ 13 Aleea Sinaia Steet, Targoviste, Romania \\ ${ }^{2}$ Ceprocim S.A. Bucharest \\ ${ }^{3}$ University Blaise Pascal Clermont II Clermont-Ferrand, France \\ E-mail: angelescu@yahoo.com
}

\begin{abstract}
Refractory concretes based on aluminous cements are used with great success in areas where high temperatures are required. The mineralogical composition of the high alumina cement is the main factor which gives the physical and mechanical properties at high temperatures of refractory monolithic materials.

It is therefore desirable to use high alumina cements based on mineralogical compounds with high refractoriness, because in the end those beneficial properties can be found in the final product - refractory concrete.

The aim of this paper is to design, realize and characterize different compositions of high alumina cements based on mineralogical compounds with the highest refractory from the $\mathrm{CaO}-\mathrm{Al}_{2} \mathrm{O}_{3}$ binary system (i.e. $\mathrm{CA}, \mathrm{CA}_{2}$, and $\mathrm{CA}_{6}$ ), and to find ways of hydraulic activation of calcium hexa aluminate, also.
\end{abstract}

Keywords: calcium monoaluminate, calcium dialuminate, calcium hexa aluminate, activated hydration, mechanical strength, additive, highly refractory compound.

\section{INTRODUCTION}

The main mineralogical constituents of high alumina cement that have hydraulic activity and which are important for the manufacture of refractory concretes are: monocalcium monoaluminate (CA) and monocalcium dialuminate $\left(\mathrm{CA}_{2}\right)$ which, by hydration, develop mechanical strength.

To achieve a refractory concrete that can be used at very high temperature, it must be use high refractory hydraulic binders such as high alumina cement with a content of alumina $\geq 70 \%$. An alternative technological option that can have the same result, and which it is showed in this paper, is to design a binder matrix whose value of molar ratio $\mathrm{Al}_{2} \mathrm{O}_{3} / \mathrm{CaO}$ is higher than the one corresponding to monocalcium dialuminate $[1,2]$.

The types of binder matrix (high alumina cements) used in this papers are base on CA6 and CA2, on CA2, CA and closer to stoichiometric CA2 (an industrial Alcoa cement).

But once the value of molar ratio $\mathrm{Al} 2 \mathrm{O} 3 / \mathrm{CaO}$ is increasing the interaction with water of the mineralogical compounds is decreasing together with it the mechanical strength decreasing, too. But in the calcium aluminates series, the refractoriness increases with the basicity decrease and enrichment in alumina as follows: $\mathrm{C} 12 \mathrm{~A} 7<\mathrm{CA}<\mathrm{CA} 2<\mathrm{CA} 6$. The mineralogical compound with the highest refractoriness from the calcium aluminates series is $\mathrm{CA} 6$, whose $\mathrm{Al} 2 \mathrm{O} 3 / \mathrm{CaO}$ molar ratio is $6: 1$. However, due to the fact that with the enrichment in alumina of the mineralogical compound the hydraulic activity decreases dramatically, the presence of CA6 was avoided [2]. To counteract this deficiency it can be use some additives with activation of hydration properties for $\mathrm{CA}_{6}$. From the great variety of high alumina cement activation of hydration must be chose the one that improve the physical and mechanical properties at room temperature and which do not affect refractoriness. One such activation of hydration is calcium sulfoaluminate. The data from literature indicates that it presence can enable interaction with water of high alumina cement, especially of the high refractory mineralogical compounds: CA2 and CA6 $[3,4]$.

\section{MATERIALS}

The raw materials used to made high alumina cements on $\mathrm{CA}_{6}$ and $\mathrm{CA}_{2}$ and, respectively, based on $\mathrm{CA}_{2}$, were reactive alumina $\left(\mathrm{Al}_{2} \mathrm{O}_{3}\right.$ content $\left.=99.50 \%\right)$ and calcium carbonate $\left(\mathrm{CaCO}_{3}\right.$ content $\left.=99.70 \%\right)$.

The raw materials used to made calcium sulphoaluminate, the activator of interaction with water for $\mathrm{CA}_{6}$ and $\mathrm{CA}_{2}$, were reactive alumina $\left(\mathrm{Al}_{2} \mathrm{O}_{3}\right.$ content $=99.50 \%)$, calcium carbonate $\left(\mathrm{CaCO}_{3}\right.$ content $=$ $99.70 \%)$ and dehydrate calcium sulphate $\left(\mathrm{CaSO}_{4} \cdot 2 \mathrm{H}_{2} \mathrm{O}\right.$ content $=99.98 \%$ ).

In order to achieve the high alumina clinkers, which by grinding were obtained cements based on $\mathrm{CA}_{2}$ and $\mathrm{CA}_{6}$ and respectively based only on $\mathrm{CA}_{2}$, we used the $\mathrm{CaO}$ - 
$\mathrm{Al}_{2} \mathrm{O}_{3}$ binary system to choose the composition of mixtures of raw materials and heat treatment temperatures.

For increasing the molar ratio $\mathrm{Al}_{2} \mathrm{O}_{3} / \mathrm{CaO}$ form high alumina cement based on $\mathrm{CA}$ and $\mathrm{CA}_{2}$ was used reactive alumina.

The high alumina cements based on high refractory compound were characterized in parallel with the additivated samples and with the increasing $\mathrm{Al}_{2} \mathrm{O}_{3} / \mathrm{CaO}$ molar ratio samples. The percent in which the additive (calcium sulphoaluminate $-\mathrm{C}_{4} \mathrm{~A}_{3} \breve{\mathrm{S}}$ ) was added to the cement is $5 \%$. The $\mathrm{Al}_{2} \mathrm{O}_{3} / \mathrm{CaO}$ molar ratio was 4.0 for the high alumina cement based on the usual cement with molar ratio $\mathrm{Al}_{2} \mathrm{O}_{3} / \mathrm{CaO}=2.5$ with addition of alumina (see Table 1).

Table 1. Oxide composition of high alumina cements

\begin{tabular}{|c|c|c|c|c|c|c|c|c|}
\hline $\begin{array}{c}\text { Cemen } \\
\text { type }\end{array}$ & $\begin{array}{c}\text { Al2 } \\
\text { O3 } \\
(\%) \\
\end{array}$ & $\begin{array}{l}\mathrm{CaO} \\
(\%)\end{array}$ & $\begin{array}{c}\mathrm{SiO2} \\
(\%)\end{array}$ & $\begin{array}{c}\mathrm{Fe} 2 \\
\mathrm{O3} \\
(\%) \\
\end{array}$ & $\begin{array}{l}\text { Alk } \\
\text { alis } \\
(\%) \\
\end{array}$ & $\begin{array}{l}\text { SO3 } \\
(\%)\end{array}$ & $\begin{array}{c}\mathrm{Mg} \\
\mathrm{O} \\
(\%) \\
\end{array}$ & $\begin{array}{l}\mathrm{CaO} \\
\text { free, } \\
(\%)\end{array}$ \\
\hline $\begin{array}{l}\text { CA6+ } \\
\text { CA2 } \\
\end{array}$ & $\begin{array}{l}85.3 \\
3 \\
\end{array}$ & 14.24 & 0.15 & $\begin{array}{l}0.1 \\
2 \\
\end{array}$ & $\begin{array}{l}0.0 \\
3 \\
\end{array}$ & 0.00 & $\begin{array}{l}0.1 \\
3 \\
\end{array}$ & 0.00 \\
\hline CA2 & $\begin{array}{l}77.6 \\
0 \\
\end{array}$ & 22.20 & 0.10 & $\begin{array}{l}0.0 \\
9 \\
\end{array}$ & $\begin{array}{l}0.0 \\
2 \\
\end{array}$ & 0.00 & $\begin{array}{l}0.0 \\
8 \\
\end{array}$ & 0.00 \\
\hline $\begin{array}{l}\mathrm{CA}+\mathrm{C} \\
\mathrm{A} 2\end{array}$ & $\begin{array}{l}70.9 \\
1\end{array}$ & 27.89 & 0.22 & $\begin{array}{l}0.2 \\
0\end{array}$ & $\begin{array}{l}0.2 \\
1\end{array}$ & 0.30 & $\begin{array}{l}0.2 \\
7\end{array}$ & 0.00 \\
\hline
\end{tabular}

\section{EXPERIMENTAL CONDITIONS}

Before starting to characterize these types of cements, they must to be identified in the $\mathrm{CaO}-\mathrm{Al}_{2} \mathrm{O}_{3}$ binary system characteristic to the super aluminous cement, shown in Figure 1.

The point shown in Figure 1 by $\mathrm{C} 1$ corresponds to the mineralogical composition of super aluminous cement based on $\mathrm{CA}_{2}$ and $\mathrm{CA}_{6}$ and $\mathrm{C}_{2}$ point corresponds to the mineralogical composition of super aluminous cement based on $\mathrm{CA}_{2}$. Regarding the location of industrially super aluminous cement composition, it is known only the fact that it can be located in $\mathrm{CA}-\mathrm{CA}_{2}$ subsystem.

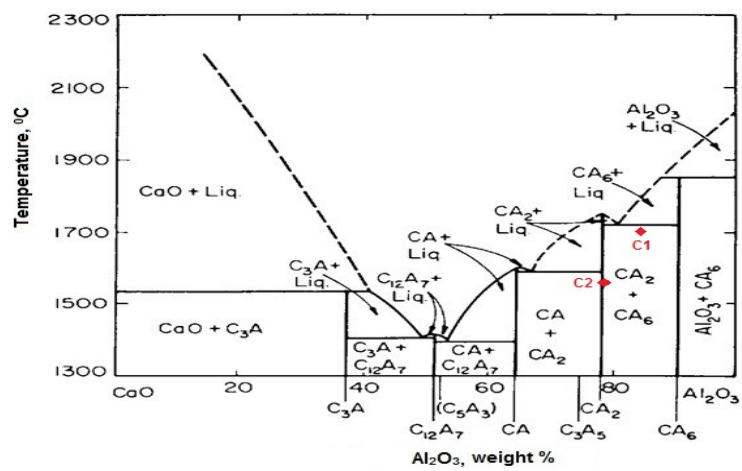

Figure 1. Phase diagram of $\mathrm{CaO}-\mathrm{Al}_{2} \mathrm{O} 3$ system

It can be seen from Table 1 that all three cements have an alumina content exceeding $70 \%$, threshold limit value considered for an aluminous cement to be use in making refractory's used in applications that can be use at very high temperatures.

In the Figures 2 to 4 are presented the X-ray diffraction spectrum of cements used in the experiments presented here in order to show that the composition corresponds to the chosen propose.

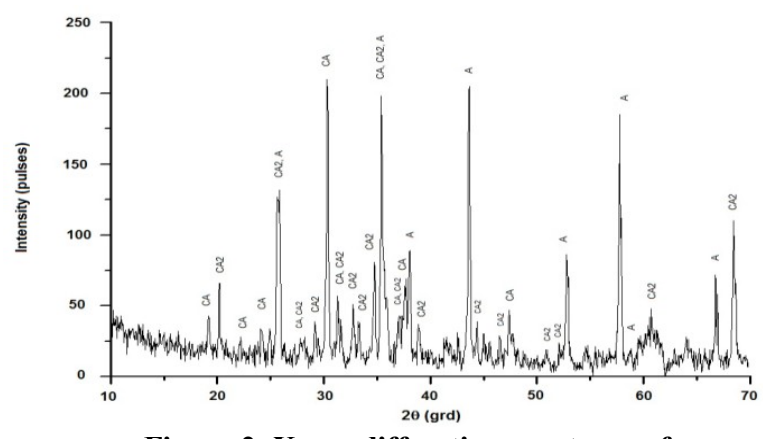

Figure 2. X-ray diffraction spectrum of super aluminous cement based on $\mathrm{CA}$ and $\mathrm{CA}_{2}$

Analyzing the peak intensity of ordinary super aluminous cement, the following mineralogical compounds were identified: CA $(2.9625 \AA, 4.6672 \AA$, $2.5132 \AA)$ and $\mathrm{CA}_{2}(3.5000,2.5990 \AA, 4.4400 \AA)$, together with $\mathrm{A}(2.0650 \AA, 2.5230 \AA, 1.5900 \AA)$.

Well defined peaks of alumina presence from the composition of ordinary super aluminous cements is explained by the fact that usually the one obtained in industrially have the composition corrected by adding alumina, thus explaining the high alumina content obtained by chemical analysis which does not correspond to the place in $\mathrm{CaO}-\mathrm{Al}_{2} \mathrm{O}_{3}$ binary system.

Analyzing the shape and intensity of the peaks corresponding X-ray diffraction spectrum of the experimental super aluminous cements presented in Figures 3 and 4, it can be seen that in the analyzed samples were formed the mineralogical compounds wanted: $\mathrm{CA}_{6}(2.4780 \AA, 2.6230 \AA, 2.1090 \AA)$ and/or $\mathrm{CA}_{2}$ $(3.5000,2.5990 \AA, 4.4400 \AA)$, corresponding to the composite selected from $\mathrm{CaO}-\mathrm{Al}_{2} \mathrm{O}_{3}$ phase diagram for these cements. Along with these compounds was also found unreacted alumina $(2.0650 \AA, 2.5230 \AA, 1.5900 \AA)$ from the raw mix.

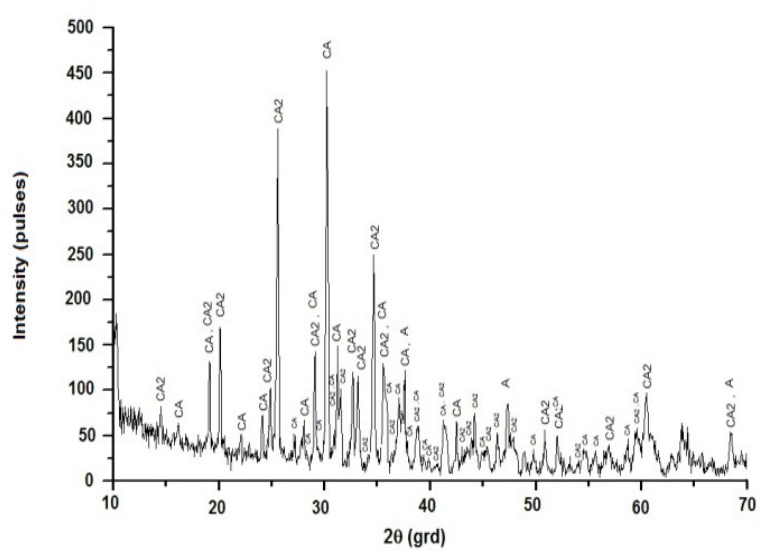

Figure 3. X-ray diffraction spectrum of super 


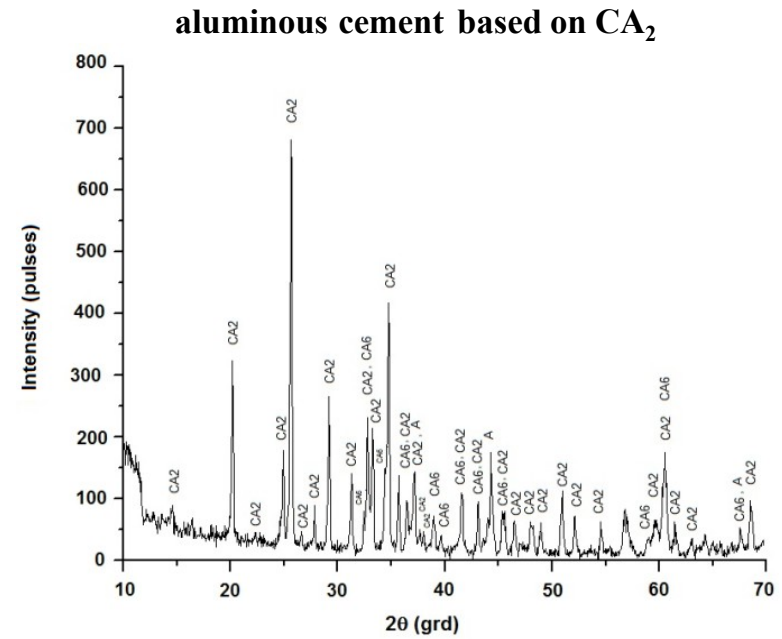

Figure 4. $\mathrm{X}$ ray diffraction spectrum of super aluminous cement based $\mathrm{CA}_{6}$ and $\mathrm{CA}_{2}$

\section{RESULTS AND DISCUSSIONS}

For a better understanding of the properties of the new high alumina cements, the results obtained after the physical and mechanical characterisation will be presented versus the ones obtained on the same cements but with $5 \%$ additive and with the one with addition of alumina, see Table 2 for characterisation at normal conditions and Table 3 for characterisation after exposure at high temperature.

Regarding the water content for standard consistency for the high alumina cements types studied in this paper is correlated with specific surface area and complies with the recommended values (see $[5,6,7]$ ).

Setting time of high alumina cements is related with the mineralogical composition. As it was anticipated from the moment of choosing the compositions of sintered alumina cement based on $\mathrm{CA}_{2}$ and $\mathrm{CA}_{6}$, the initial setting time and final setting time are much longer than those of high alumina cement based on $\mathrm{CA}_{2}$ that has a higher basicity.

With the addition of $5 \% \quad \mathrm{C}_{4} \mathrm{~A}_{3} \breve{\mathrm{S}}$ the initial and final setting times of high alumina cement were significantly shortened, Table 2 . The initial setting time was reduced by approx. $63 \%-64 \%$ and final setting time was reduced by approx. $80-84 \%$ for both high alumina cements with additive versus the samples without additives.

The values of compressive strength obtained for high alumina cement based on $\mathrm{CA}_{2}$ and $\mathrm{CA}$ with molar ratio $\mathrm{Al}_{2} \mathrm{O}_{3} / \mathrm{CaO}=2.5$ are high, even at low hydration time. This was expected because in the composition of this cement are found mineralogical compounds with high reactivity towards water.

The presence of reactive alumina lead to a very low improving of the compressive strength is attributed, probably, to the increased of workability and/or to the surface activity of the particles of alumina with positive consequence in the strength structures.
Table 2. Physical and mechanical properties of high alumina cements at $20^{0} \mathrm{C}$

\begin{tabular}{|c|c|c|c|c|c|c|c|c|}
\hline \multirow{4}{*}{$\begin{array}{l}\text { Cement } \\
\text { type }\end{array}$} & \multirow{3}{*}{$\begin{array}{c}\text { Blaine } \\
\text { specific } \\
\text { surface } \\
\text { area }\end{array}$} & \multirow{3}{*}{$\begin{array}{c}\text { Water } \\
\text { content } \\
\text { for } \\
\text { standar } \\
\mathrm{d} \\
\text { consist }\end{array}$} & \multicolumn{2}{|c|}{ Setting time } & \multicolumn{4}{|c|}{ Compressive strength } \\
\hline & & & initial & final & \multicolumn{4}{|c|}{ Terms of hydration } \\
\hline & & & & & 1 day & \begin{tabular}{|c|}
3 \\
days
\end{tabular} & \begin{tabular}{|c|}
7 \\
days \\
\end{tabular} & $\begin{array}{c}28 \\
\text { days }\end{array}$ \\
\hline & $\left(\mathrm{cm}^{2} / \mathrm{g}\right)$ & $(\%)$ & $(\min )$ & $(\mathrm{min})$ & (MPa & $(\mathrm{MPa}$ & $(\mathrm{MPa}$ & $(\mathrm{MPa})$ \\
\hline $\begin{array}{c}\text { CA2+CA } \\
6\end{array}$ & 3490 & 28.0 & 415 & 1200 & 2 & 11 & 35 & 75 \\
\hline $\begin{array}{c}\mathrm{CA} 2+\mathrm{C} \\
\mathrm{A} 6)+5 \% \\
\mathrm{C} 4 \mathrm{~A} 3 \mathrm{~S}\end{array}$ & * & 28.0 & 150 & 240 & 3 & 22 & 49 & 80 \\
\hline CA2 & 3210 & 28.0 & 320 & 960 & 38 & 59 & 72 & 76 \\
\hline \begin{tabular}{|c|}
$\mathrm{CA} 2+5 \%$ \\
$\mathrm{C} 4 \mathrm{~A} 3 \mathrm{~S}$ \\
\end{tabular} & $*$ & 28.0 & 120 & 150 & 41 & 67 & 81 & 88 \\
\hline $\begin{array}{c}\mathrm{CA}+ \\
\mathrm{CA} 2 \text { with } \\
\mathrm{A} 12 \mathrm{O} 3 / \mathrm{C}\end{array}$ & 4370 & 36.0 & 135 & 210 & 75 & 94 & 103 & 107 \\
\hline $\begin{array}{c}\mathrm{CA}+ \\
\mathrm{CA} 2 \text { with } \\
\mathrm{A} 12 \mathrm{O} 3 / \mathrm{C}\end{array}$ & * & 36.0 & 135 & 210 & 76 & 96 & 114 & 115 \\
\hline
\end{tabular}

* It assumes to be the same as the cement of whose composition we try to improve.

The compressive strength values of high alumina cements (Table 3 ) showed a strong influence to the temperature treatment at which they were exposed.

Table 3. Mechanical properties of high alumina cements after exposure at high temperature

\begin{tabular}{|c|c|c|c|c|c|c|c|}
\hline \multirow[t]{2}{*}{ Cement type } & \multicolumn{7}{|c|}{ Compressive strength (MPa) } \\
\hline & $110^{\circ} \mathrm{C}$ & $\begin{array}{l}600 \\
{ }^{6} \mathrm{C}\end{array}$ & $\begin{array}{c}800 \\
{ }^{8} \mathrm{C}\end{array}$ & $\begin{array}{l}1000 \\
{ }^{10} C^{0}\end{array}$ & ${ }^{1200}$ & $\begin{array}{c}1400 \\
{ }^{\circ} \mathrm{C}\end{array}$ & $\begin{array}{c}1600 \\
{ }^{\circ} \mathrm{C}\end{array}$ \\
\hline $\mathrm{CA}_{2}+\mathrm{CA}_{6}$ & 75 & 74 & 71 & 67 & 65 & 121 & 130 \\
\hline $\begin{array}{c}\left(\mathrm{CA}_{2}+\mathrm{CA}_{6}\right)+5 \% \\
\mathrm{C}_{4} \mathrm{~A}_{3} \mathrm{~S}\end{array}$ & 80 & 70 & 67 & 65 & 62 & 103 & 111 \\
\hline $\mathrm{CA}_{2}$ & 76 & 70 & 68 & 64 & 63 & 91 & 98 \\
\hline $\mathrm{CA}_{2}+5 \% \mathrm{C}_{4} \mathrm{~A}_{3} \mathrm{~S}$ & 87 & 69 & 65 & 60 & 59 & 84 & 90 \\
\hline $\begin{array}{c}\mathrm{CA}+\mathrm{CA}_{2} \text { with } \\
\text { molar ratio } \\
\mathrm{Al}_{2} \mathrm{O}_{3} / \mathrm{CaO}=2.5\end{array}$ & 107 & 80 & 65 & 57 & 63 & 100 & 73 \\
\hline $\begin{array}{c}\mathrm{CA}+\mathrm{CA}_{2} \text { with } \\
\text { molar ratio } \\
\mathrm{Al}_{2} \mathrm{O}_{3} / \mathrm{CaO}=4,0\end{array}$ & 115 & 86 & 83 & 76 & 80 & 113 & 102 \\
\hline
\end{tabular}

All high alumina cements showed a decrease in compressive strength in the temperature range $110^{\circ} \mathrm{C}$ $\left(1000^{\circ} \mathrm{C}\right) 1200^{\circ} \mathrm{C}$, due to structural reorganization that occurs in the critical temperature range. Instead in the range $1000^{\circ} \mathrm{C}\left(1200^{\circ} \mathrm{C}\right)-1600^{\circ} \mathrm{C}$, the values of compressive strength are improved than those recorded in the critical temperature range, this being due to the formation of ceramic binding between mineralogical 
compounds present at high temperature.

The decrease in compressive strength was higher for samples with additive, comparing to the one without additive, explained by the stronger hydration of the samples with additive. In the case on high alumina cement based $\mathrm{CA}$ and $\mathrm{CA}_{2}$ with molar ratio $\mathrm{Al}_{2} \mathrm{O}_{3} / \mathrm{CaO}$ $=4.0$, the increase of compressive strength was higher than that reported to the strength values of cement without addition of alumina. Those increased values of compressisive strength were explained by XRD and SEM.

The XRD helped to identify the mineralogical compounds presented in cement samples exposed to high temperatures, thus explaining the good behavior of the samples. After the exposure at $1600^{\circ} \mathrm{C}$ representative samples from all cements were exposure at XRD. The characteristic mineralogical components of every cement samples are presented in Table 4.

Table 4. Diffraction lines of specific mineralogical components from high alumina cements after exposure at $1600{ }^{\circ} \mathrm{C}$

\begin{tabular}{|c|c|c|c|c|}
\hline \multirow{2}{*}{ Cement type } & \multicolumn{4}{|c|}{ Calcium } \\
alumina \\
\cline { 2 - 5 } & $\mathbf{C A}_{6}$ & $\mathbf{C A}_{2}$ & $\mathbf{C A}$ & $\mathbf{A}$ \\
\hline $\mathrm{CA}_{2}+\mathrm{CA}_{6}$ & +++ & +++ & + & - \\
\hline$\left(\mathrm{CA}_{2}+\mathrm{CA}_{6}\right)+5 \% \mathrm{C}_{4} \mathrm{~A}_{3} \mathrm{~S}$ & +++ & +++ & + & - \\
\hline $\mathrm{CA} 2$ & - & +++ & + & - \\
\hline $\mathrm{CA}_{2}+5 \% \mathrm{C}_{4} \mathrm{~A}_{3} \breve{\mathrm{S}}$ & - & +++ & + & - \\
\hline $\begin{array}{c}\mathrm{CA}+\mathrm{CA}_{2} \text { with molar ratio } \\
\mathrm{Al}_{2} \mathrm{O}_{3} / \mathrm{CaO}=2.5\end{array}$ & - & +++ & ++ & - \\
\hline $\begin{array}{c}\mathrm{CA}+\mathrm{CA}_{2} \text { with molar ratio } \\
\mathrm{Al}_{2} \mathrm{O}_{3} / \mathrm{CaO}=4,0\end{array}$ & + & +++ & ++ & - \\
\hline
\end{tabular}

The XRD of the samples highlight the presence of $\mathrm{CA}_{2}$ in all high alumina cements, very well crystallized and the presence of $\mathrm{CA}_{6}$ only in cements based on $\mathrm{CA}_{2}$ and $\mathrm{CA}_{6}$ and, at the same time - in a smaller amount in the sample in which the molar ratio $\mathrm{Al}_{2} \mathrm{O}_{3} / \mathrm{CaO}$ was increased. This fact is due to the movement of the composition from the CA-CA $\mathrm{CA}_{2}$ subsystem to the $\mathrm{CA}_{2}$ $\mathrm{CA}_{6}$ subsystem for the cement with increase molar ratio $\mathrm{Al}_{2} \mathrm{O}_{3} / \mathrm{CaO}$. The crystallization of $\mathrm{CA}_{6}$, although is not very good, was favoured by high temperature and oxide composition of the sample, thus explaining the good mechanical behaviour of this sample at high temperature.

The presence of additive was not detected after heat treatment at $1600^{\circ} \mathrm{C}$, due to its low stability at temperatures higher than $1450^{\circ} \mathrm{C}$.

The samples under investigation by thermogravimetric analysis are samples of super aluminous cements hydrated for 3 days. Hydrated cement samples for 3 days were dried before tests achievement for 3 hours in desiccator on calcium chloride, because traces of water that could be in samples to not influence the tests.

Figure 5 presents the results of thermogravimetric investigations up to $1100^{\circ} \mathrm{C}$ obtained for super aluminous cements. Looking at Figure 5 we can see that with increasing temperature the mass loss is higher. These effects can be highlighted by DTG curve. It can be seen that first effect occurs around $70^{\circ} \mathrm{C}$. This mass loss can be attributed to the existence of the water physical bound and of hydrated metastable compounds $\left(\mathrm{C}_{2} \mathrm{AH}_{8}-\right.$ in the case of all cements or $\mathrm{CAH}_{10}$ - in the case of ordinary super aluminous cement) transformations in stable hydrated compounds $\left(\mathrm{C}_{3} \mathrm{AH}_{6}\right)$.

The intensity of this effect is higher for super aluminous cements based on $\mathrm{CA}$ and $\mathrm{CA}_{2}$ and for the one based on $\mathrm{CA}_{2}$. This because these cements presents more reactive mineralogical compounds in higher amounts than the one based on $\mathrm{CA}_{2}$ and $\mathrm{CA}_{6}$, because in this cement only one compound shows reactivity towards water. This does not mean that it does not present mass lose, but as it intensity is lower.

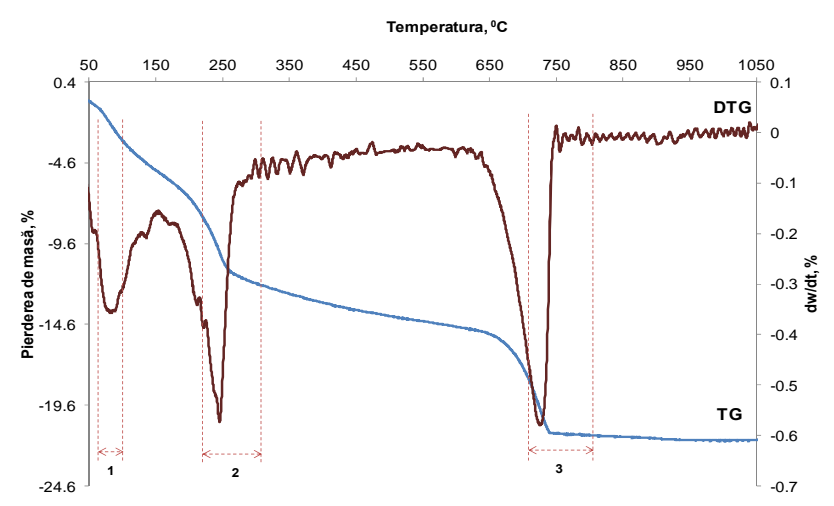

a)

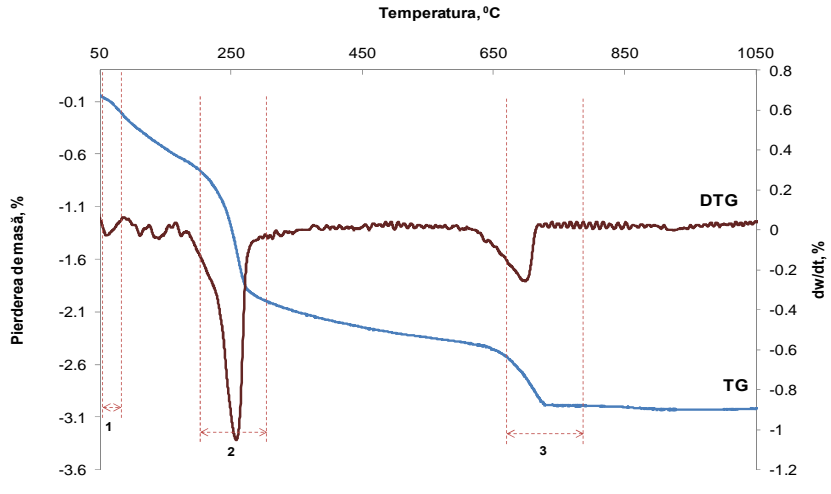

b) 


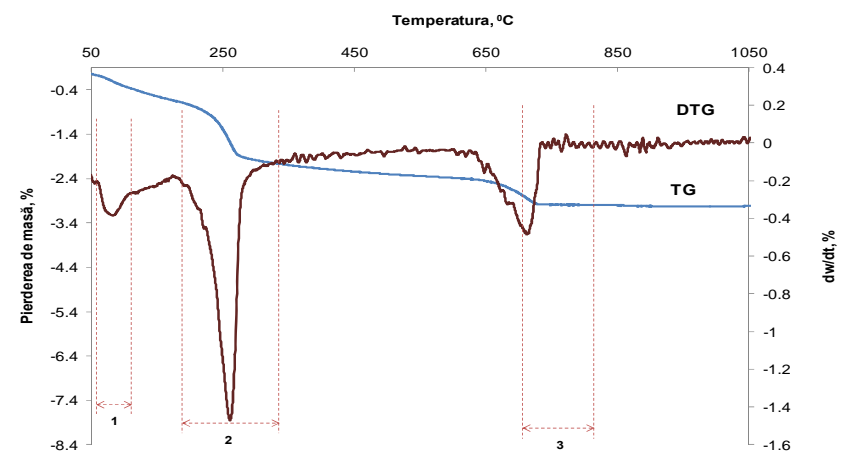

c)

Figure 5. Thermogravimetric analysis of super aluminous cements: a) $\mathrm{CA}_{\text {şi }} \mathrm{CA}_{2}$; b) $\mathrm{CA}_{2}$ şi $\mathrm{CA}_{6}$; c) $\mathrm{CA}_{2}$

The second area of mass loss occurs in the temperature range $180-280^{\circ} \mathrm{C}$, where take place the partial dehydration of $\mathrm{C}_{2} \mathrm{AH}_{8}, \mathrm{C}_{3} \mathrm{AH}_{6}$ and $\mathrm{AH}_{3}$. Data from the literature indicate that in this temperature range the dehydration of $\mathrm{C}_{3} \mathrm{AH}_{6}$ goes to $\mathrm{C}_{3} \mathrm{AH}_{1.5}$, of $\mathrm{C}_{2} \mathrm{AH}_{8}$ to $\mathrm{C}_{2} \mathrm{AH}_{4}$ and of $\mathrm{AH}_{3}$ to $\mathrm{A}[2,8,9,10,11]$, thus explained the mass loss and the high peak intensity from the curve DTG.

Regarding the third temperature range in which take place significant mass loss, this is included in the temperature range $600-730^{\circ} \mathrm{C}$. This temperature range corresponds to complete dehydration of the hydration products, with the formation of $\mathrm{C}_{12} \mathrm{~A}_{7}$ and $\mathrm{CA}$, followed at $1000^{\circ} \mathrm{C}$ only $\mathrm{CA}$ and $\mathrm{CA}_{2}$ to be meet.

In Figure 6 are presented the electron micrographs of the high alumina cements after the exposure at $1600^{\circ} \mathrm{C}$. The SEM performed on samples exposed to $1600^{\circ} \mathrm{C}$ comes to support both compressive strength values of cement samples and mineralogical compounds identified by XRD.

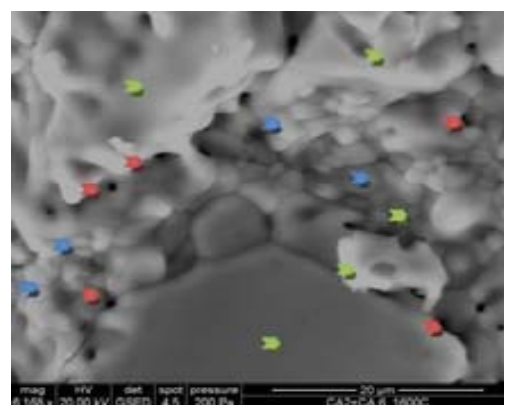

a)

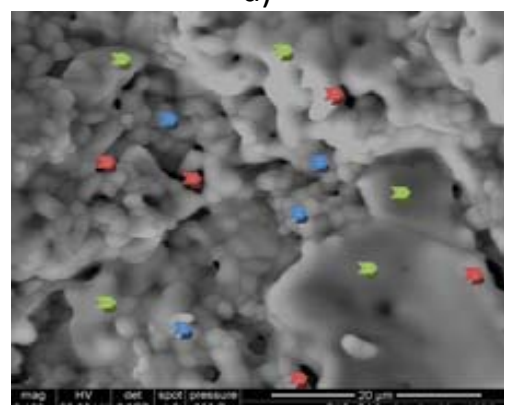

b)

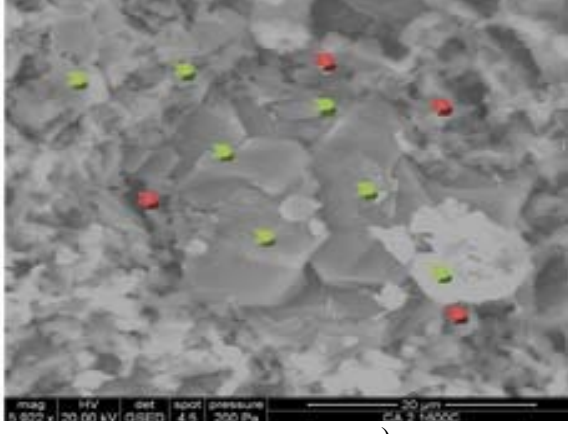

c)

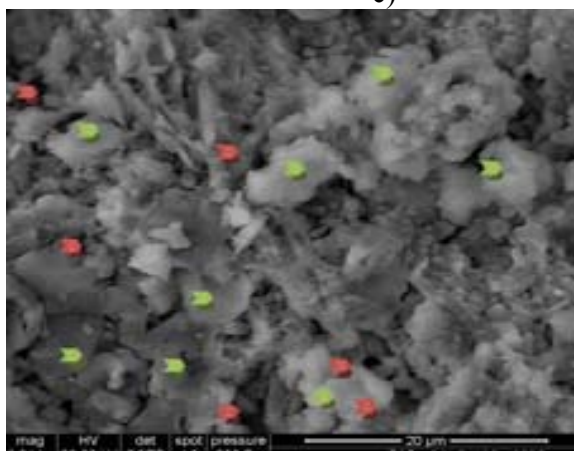

d)

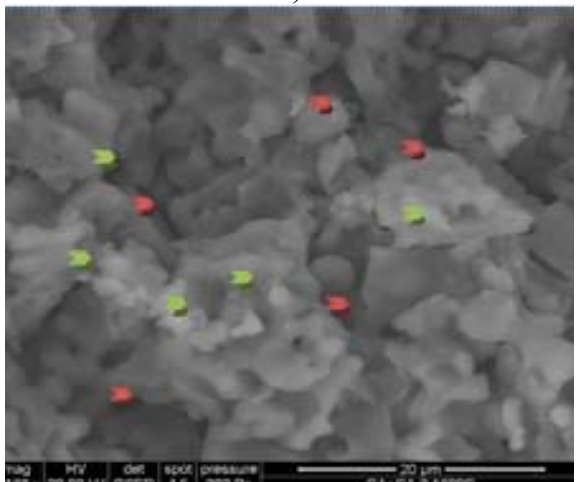

e)

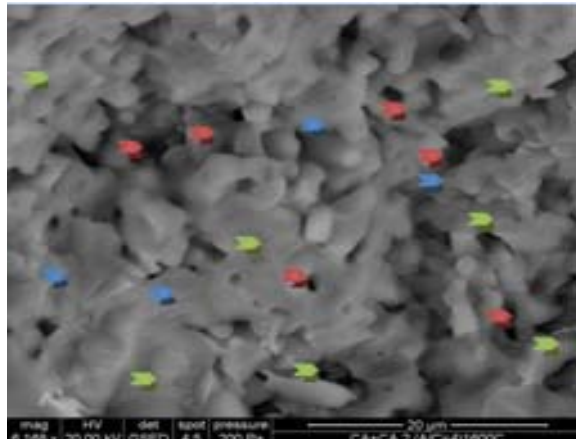

f)

Legend: $D$ CA2 crystals; $\sum$ CA6 crystals; $D$ Pores

Figure. 6. Electron micrographs of the high alumina cements based on: a) $\mathrm{CA2}$ and CA6, without additive;

b) CA2 and CA6, with $5 \%$ C4A3Š additive; c) CA2,

without additive; d) CA2, with $5 \% \mathrm{C} 4 \mathrm{~A} 3 \mathrm{~S}$ additive;

e) $\mathrm{CA}$ and $\mathrm{CA} 2$ with molar ratio $\mathrm{Al2O} / \mathrm{CaO}=2.5$; f) $\mathrm{CA}$ and $\mathrm{CA} 2$ with molar ratio $\mathrm{Al} 2 \mathrm{O3} / \mathrm{CaO}=4.0$ after the exposure at $1600^{\circ} \mathrm{C}$

It can be seen from Figure 6 that high alumina cement samples without additives shows better defined crystals ranging from $1 \mu \mathrm{m}$ up to $40 \mu \mathrm{m}$ for the sample base on 
$\mathrm{CA}_{2}$ and $\mathrm{CA}_{6}$ [Fig. 6 a)], and from $1 \mu \mathrm{m}$ up to $20 \mu \mathrm{m}$ for the sample base on $\mathrm{CA}_{2}[$ Fig. $1 \mathrm{c}$ )], lower porosity than the samples without additives [Fig. 6 b) and $c$ )], this is due to the fact that this additive is not stable at high temperatures, although it presence at normal temperature (during hydration) was favorable.

The electronic micrograph of high alumina cement with molar ratio $\mathrm{Al}_{2} \mathrm{O}_{3} / \mathrm{CaO}=4.0$ [Fig. 6 f)] revealed a structure composed of small crystals, between $1 \mu \mathrm{m}$ and $10 \mu \mathrm{m}$ belonging to $\mathrm{CA}, \mathrm{CA}_{2}$ and maybe $\mathrm{CA}_{6}$, well defined, forming a well-densified ceramic body.

Regarding the porosity of the sample, it is composed of a number of pores not very high and pore sizes go up to max. $5 \mu \mathrm{m}$. Compared with the structure of high alumina cement with molar ratio $\mathrm{Al}_{2} \mathrm{O}_{3} / \mathrm{CaO}=2.5$ without alumina [Fig. 6 e)], the structure of high alumina cement with molar ratio $\mathrm{Al}_{2} \mathrm{O}_{3} / \mathrm{CaO}=4.0$ is more compact and well crystallized due to mineralogical composition.

\section{CONCLUSIONS}

After the different investigations made on the high alumina cement based on high refractory calcium aluminous compounds we drown the following conclusions:

1. Using a hydration activator lead to improved structural and mechanical behavior of high alumina cements based on highly refractory mineralogical compounds at room temperature while maintaining the good behavior at high temperature of the base cements.

2. The high alumina cements based on high refractory mineralogical compounds such as CA2 and CA6 presented a very good structural and mechanical behavior after heat treatment at high temperature, if the normal hydration has been activated.

3. Once the molar ratio $\mathrm{Al} 2 \mathrm{O} 3 / \mathrm{CaO}$ of the high alumina cement was increase the value of compressive strength after the exposure at high temperature were increased because in the sample was found CA2 and CA6, formed by recrystallization.

4. The presence of C4A3 $\breve{S}$ was favorable at normal temperature, especially for the cements with low interaction with water, thus obtaining an increase of mechanical strengths. After heat treatment at $1600^{\circ} \mathrm{C}$, due to its low stability was not detected anymore.

\section{REFERENCES:}

[1] Angelescu, N., Ionita C. - Calcium hexa aluminate as possible mineralogical compound in alumina cements. Metallurgy and New Materials Researches, Februaries 2011, vol. 19, Special BRAMAT No, p. 11-13.

[2] Teoreanu, I., Ciocea, N. - Lianţi, mase şi betoane refractare. Ed. Tehnica, Bucharest, 1977.

[3] Munteanu, M., Ionescu, A., Ropota,,I., Munteanu,,O. Hydration of calcium aluminates in the presence of yeelenite, Calcium Aluminate Cements. Proceeding of the Centenary Conference, Breperss, 2008, p. 429-434.

[4] Ionita C. - Sisteme liante complexe folosite la obţinerea betoanelor de înaltă performanţă în contextul utilizării cimentului cu compuşi mineralogici înalt refractari. Doctorate Thesis, Valahia University Targoviste, 2013.

[5] Hewlett, P. - Lea's Chemistry of Cement and Concrete, $4^{\text {th }}$ edition. Publisher: Elsevier Science \& Technology Books, 2002, p 1057.

[6]Ionita, C., Angelescu, N., Muntean, M. - The influence of mineralogical composition of high alumina cement on its physical - mechanical properties. Proceedings of the Centenary Conference, Avignon, France, 19 May - 21 May 2014. HIS BRE Press, 2014.

[7]Ionita C., Angelescu, N., Amziane, S. - Characterization of super aluminous cements using thermogavimetry analysis and X-ray diffraction. Metalugia International vol 17 (2012), no. 6, pp. 174-177.

[8] Das, S. K., Daspoddar, P.K. - Dehydration kinetics of hydrated calcium dialuminate. Thermochimica Acta no 293, Elsevier Scientific Publishing Company, pp 125-128, 1997.

[9] Taylor, H. F. W. - Cement chemistry, 2nd edition. Publisher: Thomas Telford Publishing, 1997.

[10] Ionita, C., Angelescu, N. Abdelgader, H. S., Bratu, V., Stanciu, D., Ion, I. - The influence of hydration on the mechanical strength of the high aluminous cement. Proceedings of The International Conference on Advances in Cement and Concrete in Africa, ACCTA

2013, Johannesburg, South Africa, 2013, pp. 961 - 968.

[11]. Kumar, S., Bandopadhyay, A., Alex, T.C., Kumar, R. Influence of mechanical activation on the synthesis and hydraulic activity of calcium dialuminate. Ceramics International, no 32, pp. 555-560, 2006. 